\title{
Recenzja wydawnicza monografii Adrianny Ogonowskiej, Prawna ochrona wód morskich Morza Bałtyckiego przed zanieczyszczeniami ze statków. Aspekty prewencyjne, Wydawnictwo C.H. Beck, Warszawa 2021, ss. 259
}

\section{Temat rozprawy}

Podejmowana w recenzowanej monografii problematyka należy do aktualnych i doniosłych społecznie. Dotyczy transportu morskiego i wykorzystywanych na jego potrzeby statków, stanowiących w myśl definicji zawartej w przepisach ustawy z 2001 roku Prawo ochrony środowiska, urządzenia. Niezwykle intensywna żegluga na Bałtyku stanowi źródło zwielokrotnionego skażenia wód morskich substancjami ropopochodnymi. Zanieczyszczenia powodowane przez statki obejmują zarówno ścieki wprowadzane do ekosystemu wodnego, jak również gazy i pyły wprowadzane do atmosfery. $Z$ tego też względu poddana analizie problematyka zanieczyszczeń powodowanych przez statki musi podlegać reglamentacji prawnej. Wskazane czynniki przesądzają, że wybór tematu opracowania jest ze wszech miar aktualny i ważny ze względów zarówno społeczno-ekonomicznych, jak i ekologicznych. Jest to ciekawy temat badawczy w doktrynie prawa a recenzowana monografia stanowi jego nowatorskie ujęcie.

Za doniosłością teoretyczną podejmowanego zagadnienia przemawia fakt, że środowisko morskie należy traktować jako odrębny przedmiot działalności i legislacji ochronnej. Decydują o tym różne racje, m.in.: międzynarodowy charakter żeglugi, badania naukowe, eksploatacja dna morskiego, zjawiska zanieczyszczeń transgranicznych, mogące stworzyć zagrożenia ekologiczne o charakterze globalnym. Praca jest doniosła, po pierwsze, także ze względu na istnienie międzynarodowych konwencji, m.in. konwencji londyńskiej z 1954 roku o zapobieganiu zanieczyszczaniu morza olejami; konwencji z 1973 roku o zapobieganiu zanieczyszczeniom przez statki (konwencja MARPOL); dwóch konwencji helsińskich z 1974 i 1992 roku o ochronie środowiska morskiego obszaru Morza Bałtyckiego, czy konwencji z 2001 roku w sprawie kontroli szkodliwych systemów przeciwporostowych na stat- 
kach (konwencja AFS). Po drugie, zaliczenie na mocy art. 3 ust. 1 lit. d TfUE zachowania morskich zasobów biologicznych w ramach wspólnej polityki rybołówstwa do wyłącznej kompetencji Wspólnoty, jest podyktowane fundamentalnym znaczeniem różnorodności biologicznej zasobów morskich. UE ma także wyłączną kompetencję do zawierania umów międzynarodowych, jeżeli ich zawarcie zostało przewidziane w akcie ustawodawczym UE lub jest niezbędne do umożliwienia Unii wykonywania jej wewnętrznych kompetencji lub w zakresie, w jakim ich zawarcie może wpływać na wspólne zasady lub zmieniać ich zakres. Po trzecie, przyjęcie dyrektywy z 2008 roku ustanawiającej ramy działań Wspólnoty w dziedzinie polityki środowiska morskiego. Kolejnym kamieniem milowym było przyjęcie w 2009 roku Strategii UE dla regionu Morza Bałtyckiego. W końcu trzeba też wskazać istnienie polskiej regulacji prawnej, w tym ustaw: z 1991 roku o obszarach morskich; z 1995 roku o zapobieganiu zanieczyszczaniu morza przez statki czy z 2011 roku o bezpieczeństwie morskim.

\section{Stan badań naukowych}

Zagadnieniu ochrony środowiska morskiego przed zanieczyszczeniami poświęcono w literaturze sporo miejsca, jednakże rzadko bywa ono tematem samodzielnego opracowania i to analizowanego z punktu widzenia zanieczyszczeń powodowanych przez statki. Pierwsza polska monografia ujmująca to zagadnienie kompleksowo, autorstwa M. Górskiego, Ochrona prawna środowiska naturalnego Morza Battyckiego, została opublikowana w Łodzi w 1987 roku (obowiązujący stan prawny w roku 1984 r). Trzeba także wymienić kilka innych prac dotyczących różnych aspektów ochrony Morza Bałtyckiego, podejmowanych także współcześnie przez Autora (m.in. M. Górski, Ochrona wód morskich w świetle prawa unijnego i międzynarodowego, w: Gospodarka wodno-ściekowa w zlewni Morza Battyckiego, red. I. Zimoch, Poznań 2012).

Jednocześnie trzeba zaznaczyć, że tematem tym od wielu lat zajmują się J. Ciechanowicz-McLean i M. Nikiel (są autorami kilkunastu tekstów - rozdziały w monografiach i artykuły w czasopismach naukowych publikowanych w różnych odstępach czasu od kilkudziesięciu lat). W literaturze przedmiotu znajdujemy także publikacje odnoszące się do innego aspektu problematyki ochrony Morza Bałtyckiego przed negatywnym oddziaływaniem powodowanym przez azotany pochodzące ze źródeł rolniczych. Można tu wymienić prace Z. Bukowskiego, Zrównoważony rozwój środowiska morskiego w prawie międzynarodowym, unijnym i polskim, (w:) Gospodarka wodno-ściekowa w zlewni Morza Bałtyckiego, red. I. Zimoch, Poznań 2012, czy Gospodarka nawozami naturalnymi w Konwencji Helsińskiej o ochronie Morza Bałtyckiego oraz aktach prawa krajowego, (w:) Gospodarka wodno-ściekowa w zlewni Morza Bałtyckiego, red. I. Zimoch, Poznań 2012, a także M.A. Król, Gospodarowanie zasobami wodnymi na obszarach wiejskich a prawna ochrona Morza Bałtyckiego przed eutrofizacja, (w:) Współczesne problemy prawa rolnego i cywilnego. Księga jubileuszowa Profesor Teresy Kurowskiej, red. D. Łobos-Kotowska, P. Gała, M. Stańko, Fundacja FAPA, Warszawa 2018. 
Jednakże żadna ze wskazanych prac nie dotyczy w tak kompleksowym zakresie prawnej ochrony wód morskich Morza Bałtyckiego przed zanieczyszczeniami ze statków, co stanowi lukę wydawniczą, którą ta monografia wypełnia.

\section{Cel rozprawy i metody badawcze}

Celem monografii jest udzielenie odpowiedzi na postawione przez Autorkę pytanie, które ukazuje podstawowy problem badawczy rozprawy. Dotyczy ono analizy i oceny regulacji prawnej przepisów prawa międzynarodowego, prawa unijnego oraz polskiego prawa wewnętrznego w odniesieniu do wód morskich Morza Bałtyckiego, przed zanieczyszczeniami ze statków. Badania zawarte w opracowaniu zmierzają do uzyskania odpowiedzi na kilka pytań badawczych. Przede wszystkim, czy w systemie polskiego prawa obowiązują normy realizujące wymogi systemu prawa międzynarodowego i systemu prawa unijnego oraz jakie kwestie powinny zostać uregulowane, aby system prawa wewnętrznego realizował je w pełni. Ponadto postawiono pytanie, czy system ochronny jest efektywny i kompleksowy, i w końcu, jakie kwestie powinny zostać unormowane, aby zwiększyć stopień skuteczności i kompleksowości regulacji prawnej w badanym zakresie.

Autorka stawia ciekawe tezy badawcze, wskazując, że mała liczba regulacji polskiego prawa w tytułowej kwestii wpływa na to, że w prawie wewnętrznym nie występują normy w pełni realizujące wymogi prawa unijnego oraz międzynarodowego. Ponadto konkluduje, że instrumenty prewencyjne służące ochronie wód morskich Morza Bałtyckiego przed zanieczyszczeniami ze statków przeważają nad instrumentami kontroli i nadzoru oraz instrumentami gwarancyjnymi, co w największym stopniu przyczynia się do efektywności systemu ochronnego. W treści pracy Autorka, założony we wstępie cel realizuje i dowodzi postawioną tezę. Podejmuje również próbę oceny, zwłaszcza w zakończeniu, obowiązującej regulacji prawnej oraz sformułowania końcowych postulatów de lege ferenda, ukierunkowanych na zwiększenie dbałości ustawodawcy o kształt i treść przepisów krajowych służących osiągnięciu efektywności w walce z zanieczyszczeniami wód morskich.

Zakres niniejszej pracy, dotyczącej ochrony wód morskich Morza Bałtyckiego słusznie ograniczono do analizy instrumentów prewencyjnych przed zanieczyszczeniami powodowanymi przez statki. Trzeba ponadto zauważyć, że eksploatacja statków powoduje również emisję zanieczyszczeń do powietrza. Spalanie paliwa uwalnia do atmosfery szereg substancji zubożających warstwę ozonową. Autorka dzięki wybraniu jednego źródła zanieczyszczeń naszego akwenu morskiego mogła pogłębić rozważania w obszarze tak rozległych zagadnień badawczych. Zastosowane ograniczenie przedmiotowe wpłynęło na przejrzystość opracowania.

W pracy wykorzystano kompleks metod badawczych. Jako podstawową metodę badawczą przyjęto metodę dogmatyczno-prawną, polegającą na analizie materiału normatywnego, uzupełnioną badaniami w zakresie wykładni poszczególnych przepisów prawa i analizą poglądów prezentowanych $\mathrm{w}$ doktrynie prawa i orzecznictwie sądowym. W niewielkim 
zakresie wykorzystano metodę historyczno-prawną, dokonując analizy ewolucji prawnej omawianych instytucji, co jest uzasadnione ze względu na rozmiary opracowania.

Ogromną zaletą pracy jest jej interdyscyplinarny charakter. Recenzowana monografia obok zasadniczej części dotyczącej prawa ochrony środowiska, obejmuje także przepisy prawa morza, a więc prawa międzynarodowego publicznego. Takie ujęcie jest niezbędne do przeprowadzenia badań odnoszących się do rozwiązywania globalnych problemów ochrony środowiska morskiego, regulowanych przepisami prawa międzynarodowego i prawa UE. Z uwagi na temat pracy, ogromna jej część została poświęcona analizie prawa międzynarodowego, zwłaszcza międzynarodowych ogólnoświatowych i regionalnych konwencji.

Nie budzi zastrzeżeń dobór materiału badawczego w odniesieniu do kwestii zasadniczych. Wykorzystano monografie, materiały z sesji naukowych i konferencji oraz artykuły publikowane w czasopismach naukowych. Częściowo uzasadniony jest niewielki zakres przywołania komentarzy do polskich regulacji ustawowych, bo rzeczywiście na rynku wydawniczym mamy jedynie opracowania komentatorskie do ustawy Kodeks Morski: D. Pyć, Iwona Zużewicz-Wiewiórowska (red.), Kodeks morski. Komentarz, Lex 2012 czy Z. Brodecki (red.), Komentarz do niektórych przepisów ustawy - Kodeks morski, (w:) Prawo ubezpieczeń gospodarczych. Tom II. Komentarz, wyd. II, Warszawa 2010.

Wykaz literatury liczy 175 pozycji obejmujących pozycje naukowe i uzupełniająco popularno-naukowe (np. leksykony dyscyplin prawa). Autorka przywołuje pozycje literatury zagranicznej, co ważne z punktu widzenia przeprowadzonej analizy przepisów prawa międzynarodowego. W monografii wykorzystano też kilkadziesiąt stron internetowych, pozyskując materiały dotyczące aktualnych problemów m.in. zanieczyszczenia Morza Bałtyckiego, czy Strategii Regionu Morza Bałtyckiego. Analizie poddano orzecznictwo sądowe, w tym sądów międzynarodowych. Bibliografia zawiera wykaz wykorzystanych aktów prawnych. Dobór pozycji literatury i źródeł prawa dowodzą znajomości każdej z nich z osobna.

\section{Struktura rozprawy}

Zasadnicze rozważania zostały poprzedzone wstępem, w którym wskazano cele, zakres, tezy, metody badawcze, czy przegląd piśmiennictwa. Zasadnicza, merytoryczna część rozprawy, podzielona jest na dziewięć rozdziałów, zawiera ponadto wykazów literatury, aktów prawnych i orzecznictwa. W rozdziale pierwszym przedstawiono charakterystykę środowiska Morza Bałtyckiego. W tym kontekście zdefiniowano następujące pojęcia: środowisko morskie, wody morskie, zanieczyszczenie morza oraz statek. W rozdziale drugim przeanalizowano zagadnienie statusu prawnego wód morskich w polskim prawie wewnętrznym. W rozdziale trzecim omówiona została ewolucja prawnego systemu ochrony wód morskich Morza Bałtyckiego przed zanieczyszczeniami ze statków. W rozdziałach od czwartego do dziewiątego dokonano analizy regulacji prawnych koncentrujących się na zapobieganiu zanieczyszczeniom wód morskich pochodzącym z bezawaryjnej eksploatacji. Szczególną uwagę zwrócono na instrumenty: w zakresie postępowania z różnymi substancjami 
i ładunkami, dokumentacyjne, konstrukcyjno-wyposażeniowe, informacyjne oraz instrumenty związane z gospodarowaniem odpadami. Jednocześnie także różnorodność potencjalnych czynników zanieczyszczających znalazła odzwierciedlenie w strukturze wskazanych rozdziałów. Pogłębionej analizie poddane zostały prawne uregulowania ochrony wód morskich przed: olejowymi zanieczyszczeniami eksploatacyjnymi, zanieczyszczeniami bytowymi, zanieczyszczeniami substancjami niebezpiecznymi przewożonymi ładunkami, emitującymi do powietrza, zatapianiem zanieczyszczeń oraz przed szkodliwymi systemami przeciwporostowymi.

Taki podział pracy zapewnia komunikatywność prowadzonych rozważań. Często też poszczególne rozdziały czy podrozdziały rozpoczynają się ustaleniami terminologicznymi. To bardzo porządkuje prowadzone rozważania. Na pochwałę zasługuje umieszczenie na końcu każdego rozdziału podsumowania. Pracę kończy merytoryczne zakończenie. Praca zawiera również kilkustronicowe streszczenie w języku angielskim. Trzeba podkreślić, że sztuka strukturyzowania tekstu i frazowania wypowiedzi świadczy o biegłości warsztatu pisarskiego.

\section{Treść rozprawy}

Praca składa się z dziewięciu merytorycznych rozdziałów, wstępu i zakończenia.

Rozdział pierwszy, mimo wprowadzającego charakteru, zawiera wiele treści merytorycznych, porządkujących materię badawczą. W uwagach wstępnych Autorka bardzo krótko przedstawia stadia powstawania tego akwenu morskiego, by następnie przejść do ustaleń terminologicznych niezbędnych do dalszych rozważań. Autorka przeprowadza badania aktów prawa międzynarodowego, dokonując analizy podstawowych kategorii pojęciowych dla omawianej problematyki. Zauważa ewolucję pojęcia zanieczyszczenie w konwencjach międzynarodowych z 1974 i 1992 roku oraz pojawienie się klasyfikacji źródeł zanieczyszczeń. Biorąc to pod uwagę, słusznie stwierdza, że na gruncie prawa polskiego ustawodawca nie wprowadził dotychczas legalnej definicji pojęcia środowisko morskie, pomimo że często się tym terminem posługuje. Taka sytuacja jest wcale nierzadko spotykana w prawie polskim. Dwa kolejne punkty pierwszego rozdziału dotyczą charakterystyki środowiska morskiego Morza Bałtyckiego i statusu prawnego wód morskich w prawie polskim. Lektura tych punktów uzmysławia wyją̧tkowość ekosystemu morskiego Bałtyku, na które wpływa jego głębokość, niski poziom zasolenia, różnorodność krajobrazu związana z typami wybrzeży i warunków klimatycznych. Trzeba podkreślić, że Morze Bałtyckie należy do najbardziej zanieczyszczonych zbiorników. Autorka wskazuje zarówno źródła zanieczyszczeń, jak i ich podział ze względu na drogi przenoszenia czynników zanieczyszczających. W podsumowaniu rozdziału przytacza dane HELCOM, wskazujące poziom zanieczyszczenia morza przez statki sięgający $40 \%$ ogółu zanieczyszczeń.

Drugi rozdział poświęcono analizie międzynarodowego, unijnego i polskiego prawa, ukazującej ewolucję regulacji prawnej ochrony wód przed zanieczyszczeniem ze statków. Ciekawe są rozważania dotyczące prawnego charakteru wód morskich w prawie polskim, ich 
podział i charakterystyka. Autorka charakteryzuje status: 1) morskich wód wewnętrznych; 2) morza terytorialnego, zaznaczając, że należą do niego także redy dla portów morskich. Następnie wskazuje m.in. na zakaz wznoszenia w obu tych strefach elektrowni wiatrowych oraz konieczność uzyskania zezwolenia na konstrukcję sztucznych wysp, czy układanie kabli. Podkreśla różnice w zwierzchnictwie terytorialnym tych obszarów sprowadzającym się do prawa swobodnego przepływu czy zakaz nałożony na państwa nadbrzeżne utrudniania korzystania z wód terytorialnych np. przez pobieranie opłat za przepływ. Ostatni wskazany aspekt wiąże się bezpośrednio z tematem pracy, ponieważ dotyczy przepływu obcych statków, który powinien być szybki, nieprzerwany, nieszkodliwy i odbywać się zgodnie z przepisami zapewniającymi przestrzeganie przepisów ochrony środowiska. Inny status prawny ma już strefa przyległa i wyłączna strefa ekonomiczna, gdzie państwo nadbrzeżne ma specjalne uprawnienia. I jak podkreśla Autorka, obowiązuje na tych obszarach polskie prawo, także to odnoszące się do ochrony środowiska morskiego.

Bardzo obszerny, ciekawy rozdział trzeci dotyczy ewolucji prawnego systemu ochrony wód morskich Morza Bałtyckiego przed zanieczyszczeniami ze statków. W kilku punktach analizuje rozwój wiążących RP przepisów: 1) prawa międzynarodowego o ochronie wód morskich; 2) prawa unijnego o ochronie wód morskich; 3) polskiego prawa wewnętrznego o ochronie wód morskich. Autorka wymienia także wiele współczesnych, znaczących inicjatyw międzynarodowych w tym m.in. Bałtycki Plan Działań z 2007 roku, czy podkreśla znaczenie Ramowej Dyrektywy Wodnej dla ochrony Morza Bałtyckiego. Prowadzi także rozważania na temat tego, w jakim zakresie konstytucyjna zasada zrównoważonego rozwoju jest realizowana w międzynarodowych, unijnych i polskich regulacjach prawnych. Dokonana analiza nie wypada dla tych regulacji zadowalająco.

Konwencja przyjęta dla zasadniczej części pracy wskazuje na ujęcie tematu badawczego z punktu widzenia charakteru instrumentów prawnych chroniących wody morskie Morza Bałtyckiego: przepisów regulujących działania prewencyjne, działania kontrolne i o charakterze gwarancyjnym z tytułu zanieczyszczenia wód morskich. Autorka poświęciła swoją monografię tylko analizie instrumentów prewencyjnych. Rozdziały od czwartego do dziewiątego dotyczą instrumentów prewencyjnych jako elementu systemu prawnego służącego ochronie wód morskich przed zanieczyszczeniami związanymi z eksploatacją statków. Lektura tych rozdziałów uświadamia, że działania prewencyjne muszą się koncentrować na zapobieganiu zanieczyszczeniom pochodzącym z bezawaryjnej eksploatacji statków, bo te są źródłem znakomitej większości ścieków. Autorka zauważa i bardzo szczegółowo analizuje regulacje międzynarodowe, unijne i polskie odnoszące się kolejno do ochrony wód morskich. Przepisy prawa międzynarodowego wprowadzały od wielu lat liczne instrumenty prewencyjne, przeciwdziałające powstawaniu zanieczyszczeń. Autorka analizuje pojęcie „zrzut” w przepisach prawa międzynarodowego. Słusznie zauważa jego rozszerzający się, w stosunku do potocznego znaczenia, zakres, który obejmuje nie tylko celowe usunięcie substancji szkodliwych, ale też wszelkie wycieki, rozlania, opróżniania czy przepompowywania, o ile powoduje przedostanie się ich do morza. Autorka zauważa i zalicza do nich m.in. zakaz usuwania oleju z przestrzeni maszynowej, jak i przestrzeni ładunkowych, zakaz zrzutu na obszarze specjalnym, zrzutu substancji niebezpiecznych, nakaz prowadzenia 
dokumentacji olejowej, szczegółowe normy techniczne dotyczące konstrukcji i wyposażenia dla pomieszczeń maszynowych wszystkich statków oraz przestrzeni ładunkowej zbiorników olejowych.

Swoistym miernikiem przepisów ochronnych pozostają zawsze odstępstwa od ustanowionych zasad. Są one możliwe np. w sytuacji zapewnienia bezpieczeństwa statku, ratowania życia na morzu, ale także w sytuacji uszkodzenia statku lub jego wyposażenia. Ostatnia klauzula rodzi przestrzeń do nadużyć. Eksploatacja statków powoduje emisję zanieczyszczeń do powietrza. Spalanie paliwa uwalnia do atmosfery szereg substancji zubożających warstwę ozonową. Kwestia szkodliwości emitowanych przez statki do powietrza zanieczyszczeń, które w konsekwencji powodują zanieczyszczenie wód morskich została także przed Autorkę omówiona.

\section{Uwagi merytoryczne}

Dla sformułowania ostatecznej oceny podstawowe znaczenie ma merytoryczna zawartość pracy. Współcześnie, wobec postępującego rozwoju cywilizacyjnego zarówno w prawodawstwie międzynarodowym, jak i wewnętrznym poszczególnych państw, duży nacisk kładzie się na efektywną ochronę środowiska. Recenzowana rozprawa wpisuje się w ten nurt rozważań. We wstępie Autorka podkreśliła, że degradacja środowiska stanowi problem globalny, zaakcentowała konieczność ochrony środowiska morskiego jako dobra wspólnego.

Środowisko morskie jest elementem biosfery. Biosfera stanowi ekosystem globalny, na który składają się wszystkie ekosystemy w ich najmniejszym wymiarze. W doktrynie prawa przyjmuje się, że jest to warstwa powłoki ziemskiej (litosfery, hydrosfery, atmosfery), w której istnieją warunki rozwoju życia i która jest zasiedlana przez żywe organizmy. Ochrona biosfery, obok poprawy jakości życia, stanowi jeden z dwóch zasadniczych celów ochrony środowiska w skali lokalnej, regionalnej i globalnej. W tym ujęciu ochrona biosfery będzie obejmowała ochronę podstawowych komponentów przyrody: powietrza, powierzchni ziemi, wód, w tym wód morskich oraz zachowanie różnorodności biologicznej. Działania te są realizowane poprzez instrumenty prawne niedopuszczające do niepożądanych zmian wywołanych zanieczyszczeniami, degradacją, przekształceniami tych zasobów naturalnych, oraz poprzez zachowanie różnorodności biologicznej.

Każda dysertacja naukowa musi mieć swój temat przewodni, leitmotiv. Stanowi on o wartości tej pracy. Całość rozważań w tej monografii zmierza do uzasadnienia twierdzenia o niskim poziomie wdrożenia przepisów prawa międzynarodowego i prawa UE w zakresie ochrony wód morskich przed zanieczyszczeniami powodowanymi przez statki, pomimo istnienia przepisów prewencyjnych odnoszących się do większości problemów.

Dużym walorem monografii jest jej interdyscyplinarny charakter - w dużej części dotyczy prawa morza, a zatem publicznego prawa międzynarodowego. Znacząca część rzetelnie prowadzonych analiz odnosi się do międzynarodowych rozwiązań prawnych w zakresie prawa ochrony środowiska, przyjmowanych w formie konwencji i protokołów. Analiza prawa UE dokonywana jest pod kątem zgodności z obowiązującymi regulacjami międzyna- 
rodowymi. Rozważania dotyczące norm międzynarodowych i unijnych odnoszone są do regulacji polskich, a co ważne podkreślono różnorodne standardy ochronne w polskich unormowaniach prawnych.

Autorka zauważa, że kwestia ochrony wód morskich została podjęta stosunkowo późno i z tego względu niezbędna była natychmiastowa reakcja wymagająca zastosowania sprawnego i kompleksowego systemu ochronnego. Co istotne, stwierdza, że zagadnienie ochrony wód morskich przekracza granice państw, dlatego jest problemem globalnym, wymagającym współpracy międzynarodowej. Rozwiązanie kwestii zanieczyszczania mórz wymaga zatem zawierania umów międzynarodowych dotyczących ochrony środowiska morskiego zarówno o charakterze uniwersalnym, jak i regionalnym. W monografii podkreślono, iż środki zapobiegawcze, nadzorcze i odszkodowawcze określane są również na poziomie unijnym oraz w ustawodawstwie wewnętrznym państw nadbrzeżnych, co ma sprzyjać zwiększaniu ich skuteczności. Autorka sformułowała konkluzję, że legislacja międzynarodowa wyprzedza legislację unijną i krajową. W pracy podjęto próbę uzasadnienia dokonywanych przez ustawodawcę wyborów, np. brak polskiej regulacji w zakresie zrzutów olejowych należy interpretować jako uznanie międzynarodowych i unijnych unormowań za wystarczające i dostatecznie skuteczne.

Całość rozważań recenzowanej monografii zmierza do uzasadnienia twierdzenia o potrzebie wzmocnienia prawnej ochrony elementów środowiska morskiego przed zanieczyszczeniami powodowanymi przez statki, zwłaszcza w odniesieniu do prawa wewnętrznego. To tylko z pozoru banalne twierdzenie o potrzebie wzmocnienia instrumentów ochrony środowiska morskiego przed skutkami prowadzenia działalności polegającej na wydobywaniu działalności transportowej nie jest wywiedzione z jakichś ogólnych idei, lecz wynika z konsekwentnie realizowanych założeń badawczych w recenzowanej monografii. Jest ono efektem pewnej konfrontacji regulacji ochronnej także z wymaganiami zasady zrównoważonego rozwoju. Dzięki temu interesującemu ujęciu Autorka dokonała oceny obowiązującej regulacji prawnej, a ponadto podjęła próbę sformułowania postulatów de lege ferenda. Podzielić należy ogólny pogląd wyrażony w recenzowanej monografii o potrzebie zwiększenia ochrony środowiska morskiego, na które oddziałuje omawiana działalność transportowa.

\section{Strona formalna pracy}

Należy stwierdzić, że pod względem formalnym praca została napisana prawidłowo i czyta się ją z dużym zainteresowaniem. Monografia jest staranna, napisana ładnym, zrozumiałym, prawniczym językiem. Autorka posługuje się aparaturą językową właściwą dla prawa administracyjnego. Wykazy są rzetelnie sporządzone, znajdują odzwierciedlenie w przepisach. Stan prawny jest aktualny i należycie dokumentowany. 


\section{Wnioski}

Współcześnie poszczególne dziedziny prawa, dzięki dynamicznemu rozwojowi badań naukowych, są poddane pogłębionym i ciągle aktualizowanym analizom. Problemy naukowe powstają najczęściej na styku różnych dziedzin prawa i odzwierciedlają niedostateczny stan wiedzy w danym zakresie. Taki obszar badawczy - na styku prawa ochrony środowiska oraz prawa morskiego, a więc prawa międzynarodowego publicznego - jest przedmiotem recenzowanej rozprawy. Jest to podejście jak najbardziej słuszne i wynika ze specyfiki prawa ochrony środowiska, które jest dziedziną eklektyczną, obejmującą swoim zakresem różne dziedziny prawa.

Konkludując, stwierdzam, że recenzowana monografia to pozycja bardzo wartościowa, będąca rezultatem rzetelnej wnikliwej i dojrzałej analizy międzynarodowego, unijnego i wewnętrznego systemu prawnego i jego funkcjonowania. Może stanowić bogate źródło informacji dla kreowania rodzimych rozwiązań legislacyjnych. Będzie też z pewnością bardzo ciekawą pozycją naukową, inspirującą badaczy do dalszych dociekań.

\section{CYTOWANIE}

M.A. Król, Recenzja wydawnicza monografii Adrianny Ogonowskiej, „Prawna ochrona wód morskich Morza Bałtyckiego przed zanieczyszczeniami ze statków. Aspekty prewencyjne”, Wydawnictwo C.H. Beck, Warszawa 2021, ss. 259, Studia Administracyjne 2(14)/2021, 87-95, DOI: 10.18276/sa.2021.14-07. 